\title{
Adaptive response of the archaeon Sulfolobus acidocaldarius BC65 to phosphate starvation
}

\author{
Gonzalo Osorio and Carlos A. Jerez
}

Departamento de Bioquímica, Facultad de Medicina, Universidad de Chile, Casilla 70086,

Santiago-7, Chile
Author for correspondence: Carlos A. Jerez. Tel/Fax : +5627356384.

\begin{abstract}
The adaptive response of the archaeon Sulfolobus acidocaldarius BC65 to phosphate starvation was studied. When cells were subjected to phosphate limitation, their growth was affected. In addition, the levels of synthesis and/or the degree of phosphorylation of several proteins changed, as detected by two-dimensional nonequilibrium pH gradient electrophoresis of cells labelled in vivo with $\left.{ }^{35} \mathrm{~S}\right]$ methionine and $\left.{ }^{35} \mathrm{~S}\right]$ cysteine, or $\mathrm{H}_{3}{ }^{32} \mathrm{PO}_{4}$. After another growth-restricting treatment, a heat shock, a general inhibition of protein synthesis was observed. Under phosphate starvation conditions, a 36 kDa protein became phosphorylated without its synthesis being significantly modified, suggesting a probable regulatory role during adaptation of the cell to the change in the external environment. In Southern blot analysis with specific probes from very conserved regions of the phoR and phoB genes from Escherichia coli, a positive hybridization with $S$. acidocaldarius BC65 chromosomal DNA fragments was found. This suggested the presence in S. acidocaldarius BC65 of genes related to the E. coli genes involved in the phosphate starvation response system. This appears to be the first evidence of the possible existence of a two-component sensory system in a micro-organism from the archaeal kingdom Crenarchaeota.
\end{abstract}

Keywords: Sulfolobus acidocaldarius, Arcbaea, phosphate starvation, two-component sensory systems, adaptive response

\section{INTRODUCTION}

Bacteria sense and respond to their environment by means of signal transduction across their membranes. A major mechanism of signal transduction widespread in these cells is the so-called two-component sensory systems (Bourret et al., 1991; Stock et al., 1989; Alex \& Simon, 1994; Volz, 1995). The first component consists of a sensor, a histidine kinase that autophosphorylates a histidine residue in response to an environmental stimulus. The phosphate group is then transferred to an aspartate residue on the second component, the response regulator, which effects a cellular response. There are many signalling pathways in bacteria that are regulated by two-component systems, the best-studied being osmoregulation, nitrogen assimilation, chemotaxis and phosphate starvation (Volz, 1995; Torriani-Gorini et al., 1994).

The domain Archaea is a distinct group of prokaryotes, differing phylogenetically as much from bacteria (domain

Abbreviation: NEPHGE, nonequilibrium pH gradient electrophoresis.
Bacteria) as they do from eukaryotes (domain Eucarya) (Wheelis et al., 1992; Woese, 1987; Woese et al., 1990). The archaeal signal transduction systems are scarcely known, but evidence exists that the phototactic sensory systems in the archaeon Halobacterium balobium (kingdom Euryarchaeota) could be similar to those of bacteria (Alam \& Hazelbauer, 1991; Alam et al., 1989; Spudich, 1993; Rudolph \& Oesterhelt, 1995). Very recently, twocomponent sensory systems have also been discovered in the domain Eucarya (Chang et al., 1993; Ota \& Varshavsky, 1993; Maeda et al., 1994).

We have been studying some adaptive responses in chemolithotrophic, acidophilic micro-organisms, specifically the heat shock, phosphate starvation and chemotaxis responses (Seeger \& Jerez, 1992, 1993; Acuña et al., 1992; Jerez, 1988; Amaro et al., 1991). Therefore, we have become interested in finding out whether the Archaea might possess sensory responses that could be regulated by systems homologous to the two-component bacterial ones. We chose to study Sulfolobus acidocaldarius, a species belonging to the archaeal kingdom Crenarchaeota, which could represent the archaic ancestral ecotype (Brock, 
1991). We analysed the response of the archaeon $S$. acidocaldarius $\mathrm{BC} 65$ to phosphate starvation since the $\mathrm{PhoB}$ family of regulators is one of the most highly conserved of the bacterial two-component sensory systems (Volz, 1995). The results reported here suggest that this archaeon could respond to phosphate starvation in a way homologous to the bacterial systems.

\section{METHODS}

Bacterial strains and growth conditions. The micro-organisms employed in this study were $S$. acidocaldarius BC65, kindly provided by Paul Norris, and S. acidocaldarius DSM 639, the type strain. They were grown at $\mathrm{pH} 2.5$ and $70^{\circ} \mathrm{C}$ with rotatory shaking (120 r.p.m.) in a medium that contained $\left(\mathrm{l}^{-1}\right): 0.4 \mathrm{~g}$ $\left(\mathrm{NH}_{4}\right)_{2} \mathrm{SO}_{4}, 0.5 \mathrm{~g} \mathrm{MgSO} 4.7 \mathrm{H}_{2} \mathrm{O}, 0.2 \mathrm{~g} \mathrm{~K}_{2} \mathrm{HPO}_{4}$ and $50 \mathrm{~g}$ elemental sulfur prills as energy source (Arredondo et al., 1994). The initial inoculum was a stationary-phase cell suspension containing $10^{8}$ micro-organisms $\mathrm{ml}^{-1}$ and was usually $10 \%$ $(v / v$, final volume). Under these conditions, the generation time for both micro-organisms was around $20 \mathrm{~h}$. Growth under phosphate-limiting conditions was in the same medium, except that the phosphate salt was omitted. Thus, only the trace amount of phosphate contained in the pure salts and sulfur (all from Merck) employed was available, which was usually a maximum of $5 \times 10^{-5} \mathrm{~g} \mathrm{l}^{-1}$.

Labelling of archaeal proteins in vivo. One hundred millilitres of a control culture $\left(8 \times 10^{7}\right.$ cells $\left.\mathrm{ml}^{-1}\right)$ or a phosphate-starved culture that had reached $3 \times 10^{7}$ cells $\mathrm{ml}^{-1}$ (see Fig. 1) were incubated for $2 \mathrm{~h}$ with $14.8 \times 10^{6} \mathrm{~Bq}\left[{ }^{35} \mathrm{~S}\right]$ methionine and $\left[{ }^{35}\right.$ S]cysteine Pro-mix (specific activity $3.7 \times 10^{13} \mathrm{~Bq} \mathrm{mmol}^{-1}$; Amersham). For heat shock treatment, the same volume of control cells grown in the presence of phosphate was subjected to a heat shock at $80^{\circ} \mathrm{C}$ for $2 \mathrm{~h}$ in the presence of the same radioactive amino acids. The total radioactivity incorporated into hot trichloroacetic-acid-precipitable material was determined by scintillation counting.

For radioactive labelling of archaeal cells with $\mathrm{H}_{3}{ }^{32} \mathrm{PO}_{4}$, we used $100 \mathrm{ml}$ of a culture which had been grown in the medium with the amount of phosphate reduced to $1 / 100$ normal concentration in the case of control cells, and with no phosphate in the case of phosphate-starved cells. Reducing the phosphate concentration to $0.002 \mathrm{~g} \mathrm{l}^{-1}$ in the control treatment was done to avoid dilution of the radioactive label. Under these conditions, we obtained the same growth observed with the normal medium. Once the control cells had reached $8 \times 10^{7}$ and the phosphate-limited cells $3 \times 10^{7}$ cells $\mathrm{ml}^{-1}$, respectively, $29 \cdot 6 \times 10^{6} \mathrm{~Bq} \mathrm{H}_{3}{ }^{32} \mathrm{PO}_{4}$ (specific activity $7 \cdot 4 \times 10^{9} \mathrm{mmol}^{-1}$; Comisión Chilene Energie Nuclear) was added and incubation at $70^{\circ} \mathrm{C}$ was continued for $2 \mathrm{~h}$.

Two-dimensional nonequilibrium pH gradient electrophoresis (NEPHGE). Total cell proteins were separated by twodimensional NEPHGE, as described by O'Farrell et al. (1977), employing ampholites ( $\mathrm{pH}$ 3-10) from Bio-Rad Laboratories. The cell samples $(3.5 \mathrm{mg}$ wet wt cold cells, or the same amount of cells containing approximately $2 \times 10^{5}$ c.p.m. $\mathrm{H}_{3}{ }^{32} \mathrm{PO}_{4}$ or $1 \times 10^{6}$ c.p.m. $\left[{ }^{35} \mathrm{~S}\right]$ methionine $/\left[{ }^{35} \mathrm{~S}\right]$ cysteine) were resuspended in $100 \mu \mathrm{l}$ sonication buffer $(10 \mathrm{mM}$ Tris $/ \mathrm{HCl}, \mathrm{pH} 7 \cdot 4 ; 5 \mathrm{mM}$ $\mathrm{MgCl}_{2} ; 50 \mu \mathrm{g}$ pancreatic RNAase $\mathrm{ml}^{-1}$ ), sonicated and treated with DNAase $\left(50 \mu \mathrm{g} \mathrm{ml}^{-1}\right.$ ) (O'Farrell et al., 1977). The mixture was then lyophilized and dissolved in lysis buffer as described previously (Chamorro et al., 1988). NEPHGE gels were electrophoresed for $5.5 \mathrm{~h}$ at $400 \mathrm{~V}$. The second dimension was a SDSpolyacrylamide gel $(11.5 \%, \mathrm{w} / \mathrm{v}$, acrylamide). Molecular mass standards for the second dimension were from Bio-Rad laboratories.

Construction of oligonucleotide probes and hybridization assays. Chromosomal DNA was extracted by a phenol/ chloroform protocol modified according to Barns et al., 1994. Digestions of $S$. acidocaldarius BC65 and DSM 635 genomic DNA with restriction enzymes (from Promega) were done as described by Sambrook et al. (1989). For the Southern hybridization assays, we employed single-stranded probes corresponding to nucleotides 13-63 of the pboB gene and 1643-1692 of the phoR gene from Escherichia coli [5'-ATTCTGGTCGTAGAAGATGAAGCTCCAATTCGCGAAATGGTCTGCTTCGTG-3' (Makino et al., 1986a) and 5'-ACTTTTTT'TGCCAACGTGAGCCATGAGT'TACGTACGCCATTGACCGTGT'TA-3' (Makino et al., 1986b), respectively]. The hybridization was performed at $50{ }^{\circ} \mathrm{C}$ in the presence of $5 \times \mathrm{NaCl} /$ citrate buffer $(0.75 \mathrm{M} \mathrm{NaCl}, 0.075$ sodium citrate, $\mathrm{pH} 7.0), 0.1 \%$ sodium lauroylsarcosinate and $0.02 \%$ SDS. The probe was synthesized in the Center of Oligonucleotides of the University of Chile and was labelled with $\left[\gamma_{-}{ }^{32} \mathrm{P}\right]$ ATP by the exchange reaction (Sambrook et al., 1989).

\section{RESULTS AND DISCUSSION}

\section{Effect of phosphate starvation on growth of $S$. acidocaldarius BC65}

The effect of lack of phosphate on the growth of $S$. acidocaldarius BC65 is shown in Fig. 1. Cells stopped growing much earlier, and the final number of cells was one-sixth that of cultures grown in the presence of phosphate. Moreover, when the cells grown under phosphate-limited conditions were subcultured in a medium without phosphate, there was no further growth (data not shown). Whether $S$. acidocaldarius $\mathrm{BC} 65$ possesses phosphate reserves in the form of polyphosphates, as has been observed in other micro-organisms (Dawes, 1985), is not clear at present.

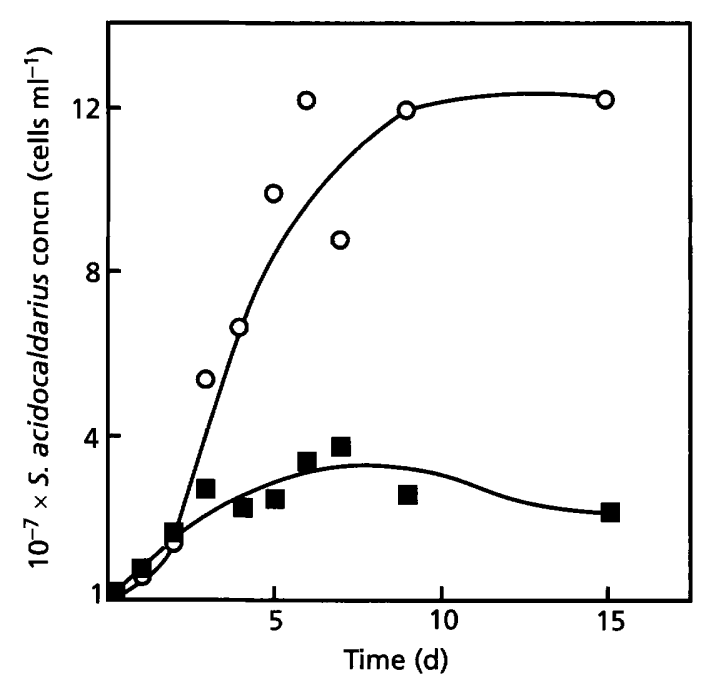

Fig. 1. Effect of lack of phosphate on the growth of $S$. acidocaldarius BC65. The micro-organism was grown with elemental sulfur as energy source and under normal $(O)$ or phosphate-limited ( $\boldsymbol{G})$ conditions. Cell concentrations were determined by direct microscopic counting. 


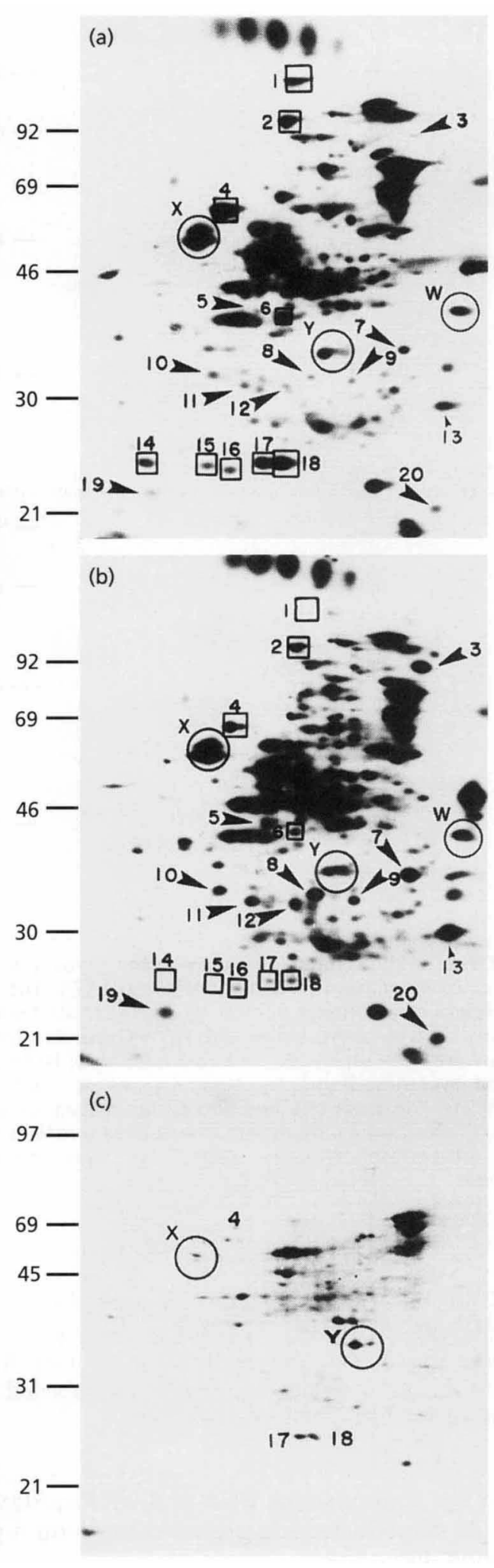

Fig. 2. Effect of phosphate starvation and heat shock on the total protein synthesis pattern in S. acidocaldarius BC65. The micro-organism was grown under normal (a) or phosphatelimited (b) conditions, or was grown under normal conditions and then subjected to a heat shock (c), and was then incubated with ${ }^{35}$ s-labelled amino acids for $2 \mathrm{~h}$. Total cell proteins were separated by two-dimensional NEPHGE with a pH gradient of 3-10 (right to left) and visualized by autoradiography. Proteins
Table 1. Relative levels of synthesis and phosphorylation of proteins from S. acidocaldarius BC65 grown under normal or phosphate-limited conditions

Relative levels were determined by computer image analysis of the autoradiograms shown in Figs 2 and 3.

\begin{tabular}{|c|c|c|c|c|c|}
\hline \multirow[t]{2}{*}{ Spot } & \multirow{2}{*}{$\begin{array}{l}\text { Molecular } \\
\text { mass (kDa)* }\end{array}$} & \multicolumn{2}{|c|}{ Synthesis } & \multicolumn{2}{|c|}{ Phosphorylation } \\
\hline & & $+\mathbf{P}_{i}$ & $-\mathbf{P}_{\mathrm{i}}$ & $+\mathbf{P}_{\mathrm{i}}$ & $-\mathbf{P}_{i}$ \\
\hline 1 & 110 & 1.42 & $0 \cdot 12$ & & \\
\hline 2 & 94 & 1.73 & $1 \cdot 37$ & & \\
\hline 3 & 88 & 0.00 & 1.74 & & \\
\hline 4 & 62 & $3 \cdot 22$ & 1.36 & & \\
\hline 5 & 42 & $0 \cdot 12$ & $1 \cdot 75$ & & \\
\hline 6 & 40 & 1.89 & $1 \cdot 17$ & & \\
\hline 7 & 36 & $0 \cdot 68$ & 1.85 & & \\
\hline 8 & 32 & 0.06 & 1.83 & & \\
\hline 9 & 31 & 0.09 & 0.69 & & \\
\hline 10 & 32 & 0.39 & 0.71 & & \\
\hline 11 & 30 & $0 \cdot 22$ & 0.74 & & \\
\hline 12 & 30 & $0 \cdot 13$ & 0.74 & & \\
\hline 13 & 29 & 0.96 & 3.60 & & \\
\hline 14 & 23 & 0.90 & 0.00 & & \\
\hline 15 & 23 & 0.42 & 0.00 & & \\
\hline 16 & 22 & $0 \cdot 49$ & 0.24 & & \\
\hline 17 & 23 & 1.49 & 0.03 & & \\
\hline 18 & 23 & 1.35 & 0.39 & & \\
\hline 19 & 22 & $0 \cdot 00$ & 0.56 & & \\
\hline 20 & 20 & 0.23 & 0.83 & & \\
\hline a & 60 & & & 1.55 & 1.67 \\
\hline$b$ & 55 & & & $2 \cdot 41$ & $1 \cdot 70$ \\
\hline c & 44 & & & $5 \cdot 08$ & 5.35 \\
\hline $\mathrm{X}$ & 56 & 6.42 & $6 \cdot 34$ & $4 \cdot 27$ & 0.00 \\
\hline$Y$ & 36 & $2 \cdot 11$ & $2 \cdot 80$ & 0.00 & $2 \cdot 83$ \\
\hline W & 42 & $1 \cdot 40$ & 1.47 & 4.93 & 0.74 \\
\hline
\end{tabular}

* The approximate molecular masses were determined by measuring the relative migration distances in the second dimension on the gel shown in Fig. 2.

\section{Changes in total protein synthesis pattern after phosphate starvation and heat shock}

Total proteins from $S$. acidocaldarius BC65 grown with sulfur as energy source and with ${ }^{35} \mathrm{~S}$-labelled amino acids were separated by two-dimensional NEPHGE and subjected to autoradiography. The results are shown in Fig. 2. We observed some proteins whose synthesis was consistently induced under phosphate starvation (arrowheads). These could represent members of a phosphate starvation response system. Conversely, the synthesis of

of interest were numbered arbitrarily. Numbers on the left of the gels indicate the positions and molecular masses in $\mathrm{kDa}$ of markers. Arrowheads and squares indicate proteins whose synthesis was consistently induced or decreased under phosphate limitation, respectively. Circles indicate phosphoproteins. 
several polypeptides (enclosed by squares) was inhibited when the cells were grown in the absence of phosphate. The proteins marked by circles are phosphoproteins (see below), the synthesis of which did not change under phosphate limitation. A summary and relative quantification of these results is shown in Table 1.

When $S$. acidocaldarius cells were subjected to another growth-restricting treatment, a heat shock for $2 \mathrm{~h}$ at $80^{\circ} \mathrm{C}$, a completely different pattern of protein synthesis was obtained, as shown in Fig. 2(c). As we (Jerez, 1988) and others (Trent et al., 1990) have described previously for $S$. acidocaldarius and Sulfolobus shibatae, respectively, a heat shock caused a decrease in the synthesis of most cellular proteins, with the preferential synthesis of a few proteins. The most actively synthesized proteins at $80^{\circ} \mathrm{C}$ were two in the $50-55 \mathrm{kDa}$ range, as described for $S$. shibatae by Trent et al. (1990). Therefore, some or most of the protein synthesis changes observed under phosphate limitation may be specific for this condition and not for any growth-limited state.

\section{Analysis of phosphoproteins and their changes during phosphate starvation}

The protein phosphorylation patterns of $S$. acidocaldarius BC65 under normal growth and phosphate starvation are shown in Fig. 3. The degree of phosphorylation of some phosphoproteins (spots X, Y and W) changed, whereas that of others (for example spots a, b and c), was not significantly modified. The coordinates of these last spots in Fig. 2 are not known at present; therefore their levels of synthesis were not determined by image process analysis (Table 1). In general, the molecular mass range of the phosphoproteins observed was similar to those previously described for $S$. acidocaldarius under normal growth conditions (Skorko, 1984). The phosphoprotein Y became greatly phosphorylated under phosphate starvation conditions. This protein could not be visualized by Coomassie-Blue-staining, and was detected only by radioactive labelling, suggesting that it is normally present in very low amounts in archaeal cells. As shown in Fig. 2, its migration was slightly shifted towards the acid side of the gel under phosphate starvation conditions, as is that of other phosphoproteins [compare spot $\mathrm{Y}$ in Fig. 2(a) and 2(b)].

As mentioned above, it is well known that many bacterial adaptive responses are regulated by phosphorylation of certain proteins comprising the so-called two-component sensory systems (Bourret et al., 1991; Stock et al., 1989; Alex \& Simon, 1994; Volz, 1995). Two-component system response regulators are known to have a size range between about 28 and $50 \mathrm{kDa}$ and are normally present in very low amounts in the cells. One could tentatively speculate that the $38 \mathrm{kDa}$ protein $\mathrm{Y}$ that became phosphorylated under phosphate starvation could represent a member of a putative two-component sensory system in S. acidocaldarius. At present we do not know what type of phosphorylation of the $S$. acidocaldarius proteins is occurring. Although the characteristic aspartyl phosphate (a)

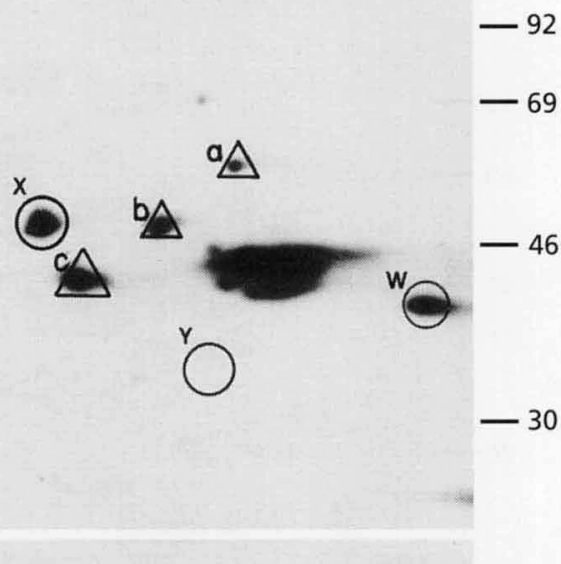

(b)

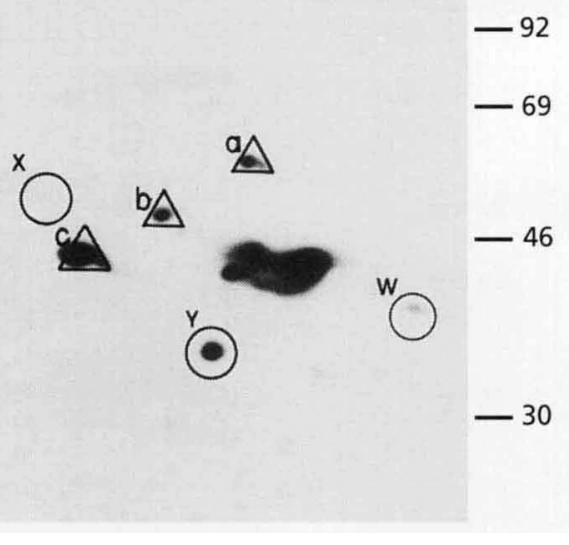

Fig. 3. Effect of phosphate starvation on the global pattern of protein phosphorylation in S. acidocaldarius BC65. The microorganism was grown under normal (a) or phosphate-limited (b) conditions. Cells were incubated with $\mathrm{H}_{3}{ }^{32} \mathrm{PO}_{4}$ for $2 \mathrm{~h}$. Total cell proteins were then separated by two-dimensional NEPHGE and visualized by autoradiography. Numbers on the right of the gels indicate the positions and molecular masses in $\mathrm{kDa}$ of markers. Circles and triangles indicate phosphoproteins whose degree of phosphorylation varied or was conserved, respectively.

present in the two-component systems has a short chemical half-life, in $E$. coli it has been possible to determine the in vivo phosphorylation of OmpR after SDS-PAGE of cell-free extracts from cells labelled in the presence of $\mathrm{H}_{3}{ }^{32} \mathrm{PO}_{4}$ (Forst et al., 1990).

\section{Probing the chromosomal DNA of S. acidocaldarius BC65 with oligonucleotide probes containing regions from $p h o B$ and $p h o R$}

If a two-component sensory system was mediating the phosphate starvation response in $S$. acidocaldarius BC65, we would expect that this archaeon contained $p h o \mathrm{R}$ - and $p h o B$-like genes in its genome. The probe used for $p h o \mathrm{R}$ contained the site of autophosphorylation of the sensor (Bourret et al., 1991; Stock et al., 1989). The probe for $p h o B$ was constructed from one of the most conserved 


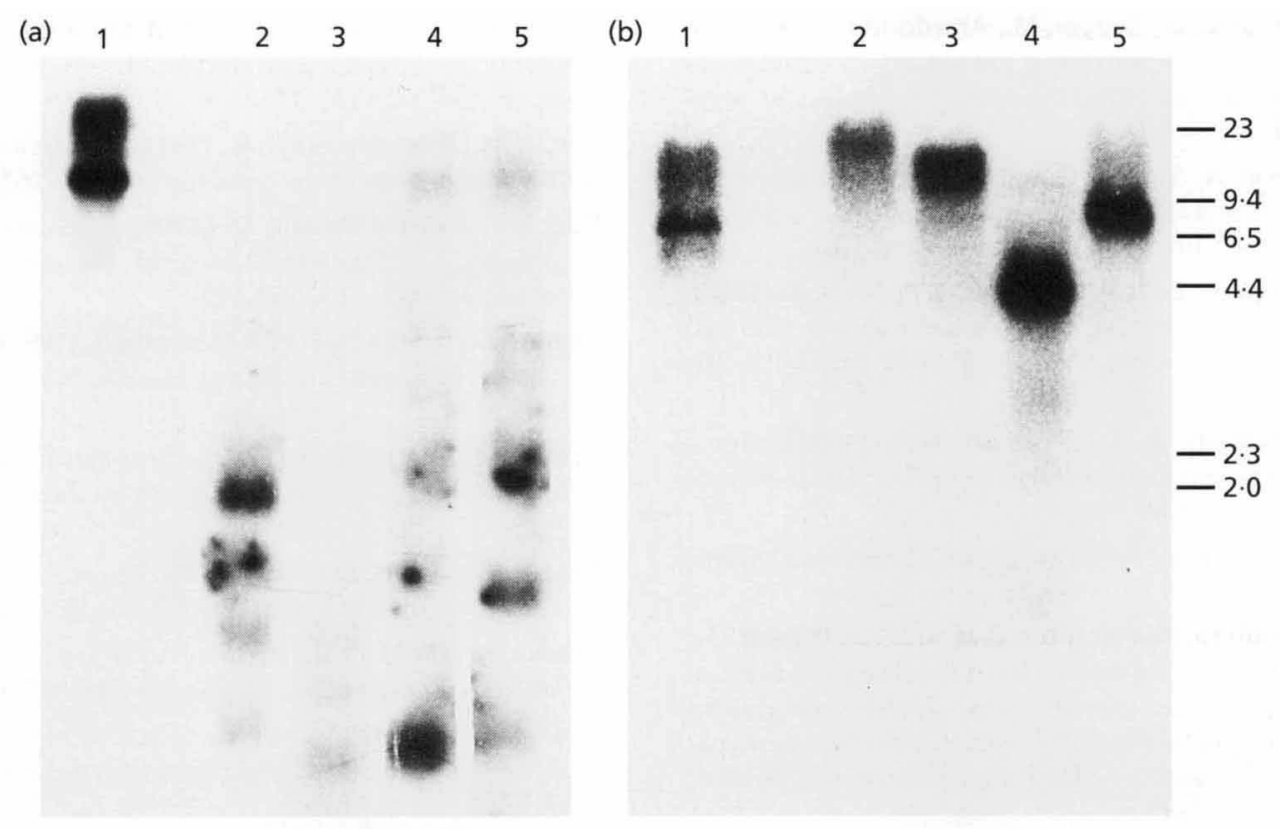

Fig. 4. Southern blot of genomic DNA of S. acidocaldarius BC65 digested with different restriction enzymes. The probes utilized were phoR (a) and phoB (b) from $E$. coli and were labelled with [ $\gamma$-32P]ATP. (a) Lanes: 1, $2 \mu \mathrm{g} E$. coli genomic DNA digested with EcoRI; 2-5, $10 \mu \mathrm{g}$ genomic S. acidocaldarius BC65 DNA doubly-digested with EcoRI and either Haell,, Ddel, Pstl or BamHI, respectively. (b) Lanes: $1,2 \mu \mathrm{g} E$. coli genomic DNA digested with EcoRI; $2-5,10 \mu \mathrm{g}$ genomic S. acidocaldarius BC65 DNA digested with BamHI, Pstl, EcoRI or Aval, respectively. Numbers on the right of the gel in (b) indicate the positions and sizes in kbp of markers.

regions in the regulatory component superfamily (Volz, 1995) (see Methods for details). As shown in Fig. 4(a), the specific probe for the phoR gene hybridized with several fragments in the $S$. acidocaldarius BC65 genome, especially with a HaeIII-EcoRI fragment of approximately $2 \mathrm{kbp}$ (lane 2) and a PstI-EcoRI fragment of approximately $0.5 \mathrm{kbp}$ (lane 4). Other restriction fragments generated with different restriction enzymes gave less clear hybridizations (lanes 3 and 5). The $p b_{o} B$ probe hybridized strongly with a $4.0 \mathrm{kbp}$ EcoRI fragment of the $S$. acidocaldarius BC65 genome (Fig. 4(b), lane 4). Other hybridization reactions were also obtained with the fragments generated by different restriction enzymes (lanes 2, 3 and 5). When $S$. acidocaldarius DSM 639 genomic DNA was employed, the same results were obtained (data not shown).

Our results clearly show that under phosphate starvation conditions the global gene expression of $S$. acidocaldarius BC65 was modified. Synthesis of several proteins was induced whereas the levels of synthesis of numerous others was decreased. We also observed a change in the global protein phosphorylation pattern under these conditions. Some of the induced polypeptides could play important roles in the phosphate response of $S$. acidocaldarius, comprising a phosphate starvation response system. The Southern blot results strongly support the existence of $p h o \mathrm{R}$ - and $p h o B$-like genes in this crenarchaeal micro-organism. This is supported by the very recent finding of a histidine kinase in a two-component system from an euryarchaeal micro-organism (Rudolph \& Oesterhelt, 1995), which indicates that both archaeal kingdoms possess this class of sensorial systems. In evolutionary terms, the presence of two-component systems in the two principal evolutionary lineages (Bacteria and Archaea-Eucarya) (Chang et al., 1993; Ota \& Varshavsky, 1993; Maeda et al., 1994) would indicate that these systems emerged in the common ancestor (assuming no gene transfer between domains). Since the domain Archaea is a slowly evolving group, one would expect it to have retained this type of sensory system.

\section{ACKNOWLEDGEMENTS}

This work was supported by grants from FONDECYT 194/0379, FONDECYT 2950019, UNIDO $91 / 049$ and SAREC.

\section{REFERENCES}

Acuña, J., Rojas, J., Amaro, A. M., Toledo, H. \& Jerez, C. A. (1992). Chemotaxis of Leptospirillum ferrooxidans and other acidophilic chemolithotrophs: comparison with the Escherichia coli chemosensory system. FEMS Microbiol Lett 96, 37-42.

Alam, M. \& Hazelbauer, G. L. (1991). Structural features of methylaccepting taxis proteins conserved between archaebacteria and eubacteria revealed by antigenic cross-reaction. $J$ Bacteriol 173, 5837-5842.

Alam, M., Lebert, M., Oesterhelt, D. \& Hazelbauer, G. L. (1989). Methyl-accepting taxis proteins in Halobacterium balobium. EMBO J 8, 631-639.

Alex, L. A. \& Simon, L. I. (1994). Protein histidine kinases and signal transduction in prokaryotes and eukaryotes. Trends Genet 10, 133-138. 
Amaro, A. M., Chamorro, D., Seeger, M., Arredondo, R., Peirano, I. \& Jerez, C. A. (1991). Effect of external $\mathrm{pH}$ perturbations on in vivo protein synthesis by the acidophilic bacterium Tbiobacillus ferrooxidans. J Bacteriol 173, 910-915.

Arredondo, R., García, A. \& Jerez, C. A. (1994). Partial removal of lipopolysaccharide from Thiobacillus ferrooxidans affects its adhesion to solids. Appl Environ Microbiol 60, 2846-2851.

Barns, S. M., Fundyga, R. E., Jeffries, M. W. \& Pace, N. R. (1994). Remarkable archaeal diversity detected in a Yellowstone National Park hot spring environment. Proc Nat Acad Sci USA 91, 1609-1613.

Bourret, R. B., Borkovich, K. A. \& Simon, M. I. (1991). Signal transduction pathways involving protein phosphorylation in prokaryotes. Annu Rev Biocbem 60, 401-441.

Brock, T. D. (1991). Biology of Microorganisms. Englewood Cliffs, New Jersey: Prentice Hall.

Chamorro, D., Arredondo, R., Peirano, I. \& Jerez, C. A. (1988). The programme of proteins synthesized by Thiobacillus ferrooxidans under different environmental conditions: analysis by two dimensional gels. In Biobydrometallurgy 1987, Symposium Proceedings, pp. 135-143. Edited by P. Norris \& D. Kelly. Kew, Great Britain: Science and Technology Letters.

Chang, C., Kwok, C. F., Bleecker, A. B. \& Meyerowitz, E. M. (1993). Arabidopsis ethylene-response gene etr1: similarity of product to two-component regulators. Science 262, 539-544.

Dawes, E. A. (1985). Starvation survival and energy reserves. In Bacteria in their Natural Environments, pp. 43-79. Edited by $M$. Fletcher \& D. Floodgate. London: Academic Press.

Forst, S., Delgado, J., Rampersaud, A. \& Inouye, M. (1990). In vivo phosphorylation of $O \mathrm{mpR}$, the transcription activator of the ompF and the ompC genes in Escherichia coli. Proc Natl Acad Sci USA 172, 3473-3477.

Jerez, C. A. (1988). The heat shock response in meso- and thermophilic chemolithotrophic bacteria. FEMS Microbiol Lett 56, 289-294.

Maeda, T., Wurgler-Murphy, S. M. \& Saito, H. (1994). A twocomponent system that regulates an osmosensing MAP kinase cascade in yeast. Nature 369, 242-245.

Makino, K., Shinagawa, H., Amemura, M. \& Nakata, A. (1986a). Nucleotide sequence of the $p h o B$ gene, the positive regulator gene for the phosphate regulon of Escherichia coli K-12. J Mol Biol 190, $37-44$.

Makino, K., Shinagawa, H., Amemura, M. \& Nakata, A. (1986b). Nucleotide sequence of the $p h o \mathrm{R}$ gene, a regulatory gene for the phosphate regulon of Escherichia coli. J Mol Biol 192, 549-556.
O'Farrell, P. Z., Goodman, H. M. \& O'Farrell, P. H. (1977). High resolution two-dimensional electrophoresis of basic as well as acidic proteins. Cell 12, 1133-1142.

Ota, I. M. \& Varshavsky, A. (1993). A yeast protein similar to bacterial two-component regulators. Science 262, 566-569.

Rudolph, J. \& Oesterhelt, D. (1995). Chemotaxis and phototaxis require a CheA histidine kinase in the archaeon Halobacterium salinarum. EMBO J 14, 667-673.

Sambrook, J., Fritsch, E. F. \& Maniatis, T. (1989). Molecular Cloning: a Laboratory Manual. Cold Spring Harbor, NY: Cold Spring Harbor Laboratory.

Seeger, M. \& Jerez, C. A. (1992). Phosphate limitation affects global gene expression in Thiobacillus ferrooxidans. Geomicrobiol $J$ 10, 227-237.

Seeger, M. \& Jerez, C. A. (1993). Response of Thiobacillus ferrooxidans to phosphate limitation. FEMS Microbiol Rev 11, 37-42.

Skorko, R. (1984). Protein phosphorylation in the archaebacterium Sulfolobus acidocaldarius. Eur J Biochem 145, 617-622.

Spudich, J. L. (1993). Color sensing in the Archaea : a eukaryotic-like receptor coupled to a prokaryotic transducer. $J$ Bacteriol 175, 7755-7761

Stock, J. B., Ninfa, A. J. \& Stock, A. M. (1989). Protein phosphorylation and regulation of adaptative responses in bacteria. Microbiol Rev 53, 450-490.

Torriani-Gorini, A., Yagil, E. \& Silver, S. (1994). Phosphate in Microorganisms: Cellular and Molecular Biology. Washington, DC: American Society for Microbiology.

Trent, J. D., Osipiuk, J. \& Pinkau, T. (1990). Acquired thermotolerance and heat shock in the extremely thermophilic archaebacterium Sulfolobus sp. strain B12. J Bacteriol 172, 1478-1484.

Volz, K. (1995). Structural and functional conservation in response regulators. In Two-Component Signal Transduction, pp. 53-64. Edited by J. A. Hoch \& T. J. Silhavy. Washington, DC: American Society for Microbiology.

Wheelis, M. L., Kandler, O. \& Woese, C. R. (1992). On the nature of a global classification. Proc Natl Acad Sci US A 89, 2930-2934.

Woese, C. R. (1987). Bacterial evolution. Microbiol Rev 51, 221-271.

Woese, C. R., Kandler, O. \& Wheelis, M. L. (1990). Towards a natural system of organisms: proposal for the domains Arcbaea, Bacteria, and Eucarya. Proc Natl Acad Sci US A 87, 4576-4579.

Received 19 September 1995; revised 2 January 1996; accepted 12 January 1996. 